\title{
Emotional Intelligence as a Tool for Developing Entrepreneurial Professional Networks
}

\author{
Wilbert R. Mutoko \\ Senior Lecturer/Course Manager, School of Business and Leisure \\ Botswana Accountancy College, Private Bag 00319, Gaborone, Botswana \\ Tel: +267-395-3062. Mobile: +267-7182-4591 \\ E-mail: wilbertmutoko@gmail.com \\ Jennifer Chishamiso Nzonzo (Corresponding Author) \\ Lecturer, School of Business and Economics \\ Monash University, South Africa \\ Tel: 0027119504042 \\ Email: jennifer.nzonzo@monash.edu
}

Received: December 12, 2015 Accepted: January 08, 2016 Published: April 08, 2016

doi:10.5296/jebi.v3i1.9284 URL: http://dx.doi.org/10.5296/jebi.v3i1.9284

\begin{abstract}
This paper seeks to investigate how Emotional Intelligence (EI) impacts on the relationship between entrepreneurial competence and the development of professional networks. A qualitative methodology was adopted in this survey using structured face-to-face interviews which were administered to a sample of 10 entrepreneurs who own manufacturing Small Medium and Micro Enterprises (SMMEs) based in Gaborone, Botswana. Thematic analysis was used as data analysis strategy. The key findings of the research are that firstly, EI plays an important role in developing professional networks. Secondly, the main benefits of networking are advice; friendship; information sharing and training opportunities. Thirdly, entrepreneurs develop entrepreneurial professional networks through networking with individuals of their own nationality; engaging with other members of the local business community and international networks. This study has provided important insights of interest, to entrepreneurs, scholars and policy makers. However the research was based on a qualitative methodology, future research can be undertaken using a mixed methodology. Furthermore additional research can be undertaken using a comparative analysis of different
\end{abstract}


African countries in order to come up with a multifaceted approach to the role of EI in the development of entrepreneurial professional networks. This paper motivated a debate on the link between EI and the development of professional networks and how these variables determine Entrepreneurial success. While there appears to be a clear relationship between EI and the development of entrepreneurial networks measurement instruments that can show the contributions of each variable to entrepreneurial success need to be contextualised.

Keywords: Emotional intelligence, Entrepreneur, Networks, Social capital, Emotional competence

\section{Introduction}

Contemporary research on entrepreneurship has highlighted that entrepreneurs may have considerable knowledge about market niches. However, despite market niche knowledge they face challenges on how they can effectively develop their professional networks. Such challenges usually disadvantage them and insulate them from the latest ideas and trends on how they can effectively position themselves in the business landscape. This is because information on suppliers, regulators, customers, sources of funding and opportunities for growth may not be accessible if an individual does not network with others. Botswana, like other countries faces challenges in the creation and development of entrepreneurial skills (Chinyoka \& Muranda, 2013). As such, the development of professional networks is adversely affected.

Due to the fact that entrepreneurial skills are not innate, and also given the importance of the cultural and economic contexts, it is important to adapt the support programs aimed at entrepreneurs by being culture and context sensitive (Briere, Tremblay, \& Daou, 2014; Chipfuva, Nzonzo, \& Muchenje, 2012; Suleiman Awwad \& Kada Ali, 2012). Central to this argument is the fact that modern day management practices have led to the realisation that understanding the business means there should be a multiplicity of information available to inform business decisions. For instance, in a research by (Pansiri \& Temtime, 2008) in Botswana it was found out that entrepreneurial aspirations had played an essential role in promoting entrepreneur's motivations, managerial competence, the ability to take risks , self-competence, and developing business opportunities. This therefore highlights the importance of EI as an essential aspect in entrepreneurial success. Furthermore, there is also an enormous benefit to be realised if EI is integrated within the business domain. Consequentially, a successful entrepreneur is one that focuses on analysing the macro and micro factors that hinder or promote business effectiveness as well as enhance the development of professional networks. This study seeks to investigate how EI impacts on the relationship between entrepreneurship competence and the development of professional networks. This article starts by highlighting the literature on emotional intelligence and the development of professional networks. The research methodology is expounded. Results and implications follow. The article winds up by highlighting study limitations and areas for future research. 


\section{Literature Review and Conceptual Model}

\subsection{The Importance of Emotional Intelligence in Entrepreneurship}

EI is the intellectual processes involved in the recognition, use, understanding, and management of one's own and others' emotional states and the ability to use those feelings to motivate, plan, and achieve goals (Brooks \& Muyia Nafukho, 2006). From a practical point of view, EI is the application of emotions wisely in situations that call for emotionally guarded rather than logically smarter responses (Kunnanatt, 2004). Taking into cognisance the two definitions provided. EI may be broadly defined as the set of verbal and non-verbal abilities that enable an individual to generate, recognize, express, and evaluate their own emotions in order to guide their own action and cope with demands and pressures from social interactions. From the point of view of a national economy, entrepreneurship is very important. This is mainly because business ventures are important tasks for policy makers as they contribute to sustainable economic development (Prakash, Jain, \& Chauhan, 2015). Various economic theories have evolved and influenced organisational operations in the $19^{\text {th }}$ century. This evolution has expanded the traditional forms of capital, such as tangible assets like buildings and equipment, and now includes social capital. These intangibles likewise contribute to entrepreneurial development and growth. Thus, the term capital has gained currency in the literature, which has given rise to several variations of capital discussed in current literature (Brooks \& Muyia Nafukho, 2006). Ultimately, the need to manage emotion which is part of social capital has now become an essential part of entrepreneurship. Resultantly, professionals and academics continually contend with the issues associated with organizing, motivating, enhancing, and enhancing EI. As such, thinking about entrepreneurship in the context of economic growth makes it "apparent that the engine of economic growth is entrepreneurship" (Hafer \& Jones, 2014; Makgosa \& Ongori, 2012). Moreover, the challenges emanating from the economic environment have led to the realisation that entrepreneurs need to be innovative and develop new ideas, products, and processes, and be willing to take risks in order to cope with change. Accordingly, It is therefore relevant to investigate the skills and characteristics of entrepreneurs that play a pivotal role in enhancing the capacity and capability of entrepreneurs (Neneh \& Van Zyl, 2013).

\subsection{Developing Professional Entrepreneurial Networks}

Entrepreneurial networks are the sum total of relationships, both formal and informal; in which entrepreneurs participate and draw benefits as either a business person or as an organisation (Galkina, 2013). To reiterate the essence of entrepreneurial networks, (Sullivan, 2006) states that entrepreneurs use other people's assistance through networks to obtain resources needed in new venture creation. (Thoma, Nguyen, \& Kupsyte, 2014a) further argue that networks are crucial tools in the start-up phase of a firm, and during the growth process. Thus, entrepreneurial networking provides a platform for establishing and maintaining effective professional networks. 


\subsection{The importance of Networking}

There are a number of reasons why entrepreneurs should network (Kay, 2010):

- More contacts may translate into more career opportunities;

- Good relationships at work help in new circumstance;

- Strong personal networks can increase job satisfaction;

- Problem solving is done faster when entrepreneurs are highly networked;

- There is greater access to employment, industry and other information;

- Networking arises new collaborative opportunities with other organisations

- There is room to develop long-term professional relationships.

These points raised by (Kay, 2010) can be summed up in one word - progress.

\subsubsection{How to Make Entrepreneurial Networking Effective}

Networking is a reciprocal game. Whatever an entrepreneur wants others to do for him/her; s/he should be willing to do it first (Kay, 2010). Networking is not for the selfish. It is a 'give and take relationship.' Entrepreneurs therefore need to find how they can be of help to others, give that and then expect to be helped. Failure to do that means failure to network effectively.

\subsubsection{Network Structure}

Every network has two main components nodes and connections. In an entrepreneurial context, nodes are substituted for individuals; while connections are represented by social knots and bonds (Thoma, Nguyen, \& Kupsyte, 2014b). Thus, an entrepreneurial network is comprised of a series of direct and indirect interpersonal ties from one entrepreneur to others around him/her to bring benefits (Hallen \& Eisenhardt, 2012). The social knots usually comprise strong interpersonal ties, for example family and close friends; and weak interpersonal ties such as competitors, acquaintances and colleagues. Every entrepreneur has a small collection of direct but very helpful ties and a big collection of indirect ties. Therefore, an entrepreneur should aim to increase or broaden and strengthen the indirect ties to maximize benefits of networking. Unfortunately, most entrepreneurs are so busy in their business activities and they don't set aside time to diversify their network.

\subsubsection{Forms of Entrepreneurial Networking}

In the 21st Century, Entrepreneurial Networking comes in two major forms - that is direct contact of the entrepreneur with other parties, and through social media (Kay, 2010). Social media happens over the internet and includes platforms such as Face book, Twitter, LinkedIn, You Tube, Blogs, Websites, Flickr and many others (Kaplan \& Warren, 2009). An entrepreneur has to choose which platform serves them and their form of business best (Jefferis, 2014; Kaplan \& Warren, 2009). For instance, Face Book is a popular personal networking to keep in touch with friends and relatives. Although some people make money on Face Book, it generally assumed that this platform is personal. The power of Face Book 
cannot be underestimated because as of October 2012, the network users reached the 1 billion mark (Money, 2012). LinkedIn, on the other hand is mainly for professionals. Therefore, one can be on both networks, but knowing what they should input and output from each network.

\subsection{The Interlinkage between Emotional Intelligence and Developing Entrepreneurial Networks}

Social capital is thought to be the most important form of capital for entrepreneurs. It enables entrepreneurs to have the opportunity to collaborate with others, develop business opportunities and facilitate problem solving. Within the context of developing networks social capital provides a mechanism for entrepreneurs to expose their business ideas to the business community (Briere et al., 2014). Resultantly, the ability to effectively network as an entrepreneur is contingent upon personal conviction of achieving goals and economic optimization via a robust social networking. Hence, entrepreneurial performance has been linked to cognitive and social skills and psychological measures have attempted to assist in the identification of cognitive and social factors that affect entrepreneurial performance as well as techniques that assist in coping with the lack of social or cognitive abilities. Through this process, psychologists have suggested training on social and interpersonal skills that may be vital to the entrepreneurial process. Furthermore, several skills and abilities have been identified as determinants of successful interaction with others including accurately perceiving others, making good first impressions, and the ability to persuade or influence others (Oriarewo, Agbim, \& Zever, 2014). Entrepreneurial activity is increasingly organized around networks. Networks constitute an essential part of interactions and the diffusion of networking logic substantially modifies the operation and outcomes in terms of business performance. The ability to network professionally can have a strong influence on entrepreneurial activity because entrepreneurs are embedded in the social contexts that influence their decisions. To validate this point (Thi Thanh Thai, Turkina, \& Stephens, 2013) posit that studies of the social networking activities of immigrant entrepreneurs reveal that immigrant entrepreneurs often face challenges of integrating in new cultures. Specifically, this line of argument highlights the challenges of cultural assimilation entrepreneurs' face when developing networks. Resultantly entrepreneurs will have to focus on the development of their emotional competence. Entrepreneurial competence is the sum total of the entrepreneur's intangible attributes which includes attitudes, values, beliefs, knowledge, skills, abilities, personality, wisdom, expertise, and behavioural propensities (Oriarewo et al., 2014). The more skilled entrepreneurs are, the more entrepreneurial they behave, and the higher their enterprisese performance levels (Chinyoka \& Muranda, 2013). Likewise entrepreneurs who display passion about developing networks tend to perform better as compared to those who do not perform better. In essence EI may play a critical role in an entrepreneur's ability to present to investors, bankers, venture new customers, friends and family, in order to obtain financing and improve business capacity.

\subsection{Conceptual Model}

As depicted in the literature review highlighted in the previous sections the goal of EI, is to facilitate individuals in developing self-knowledge about their emotions in order to guide 
them smoothly toward interpersonal success. Knowledge of EI is pivotal in developing entrepreneurial professional networks. Based upon the literature review the conceptual model which is most suitable for showing how emotional intelligence can aide in developing entrepreneurial professional networks is the one proposed by (Kunnanatt, 2004). Fig 1 depicts the conceptual framework.

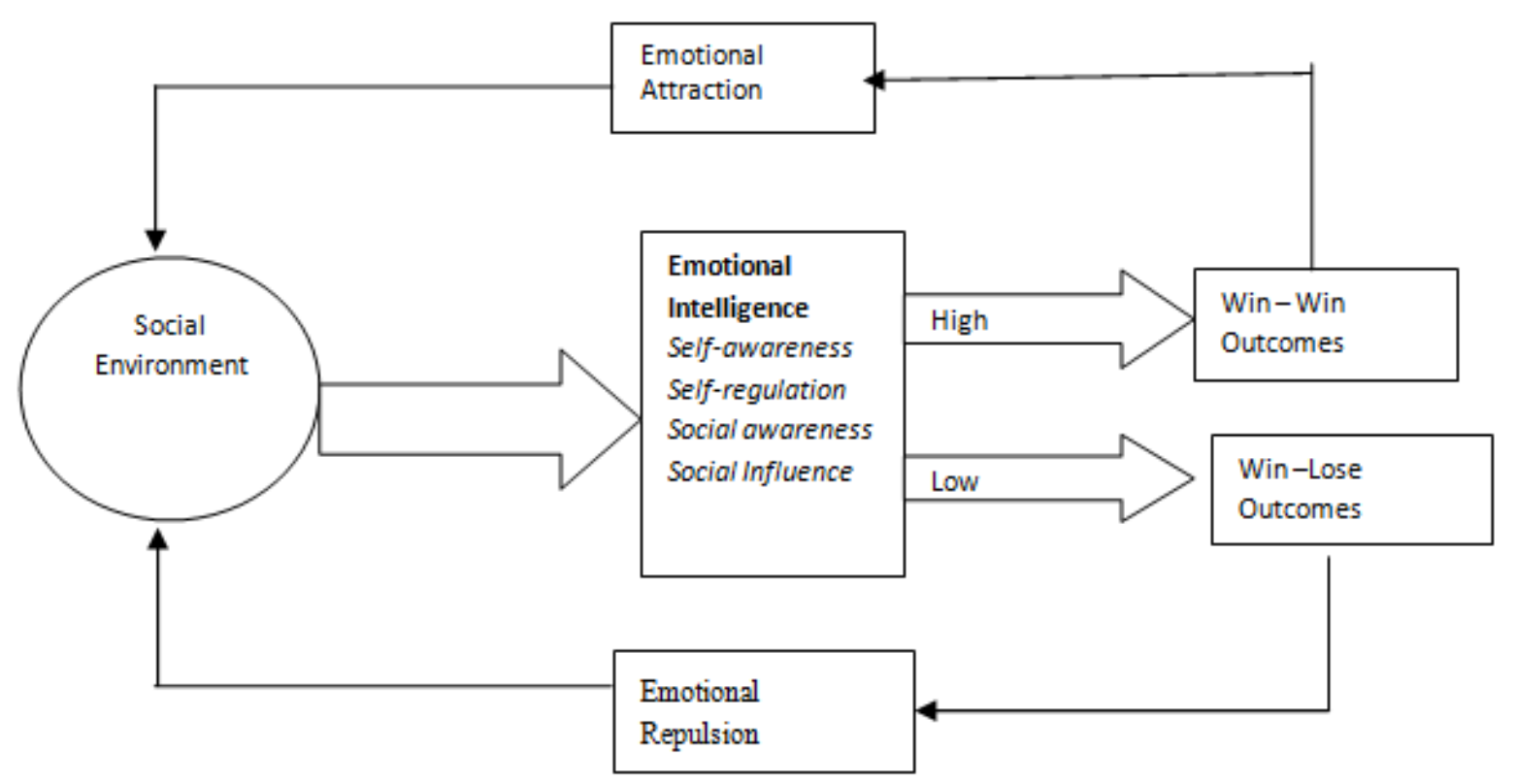

Figure 1. A model of Emotional Intelligence

Source: (Kunnanatt, 2004).

The model is based upon the premise that the social environment plays an essential role in moderating the emotions of an individual. Thus, emotional intelligence is composed of self-awareness, self-regulation, social awareness and social influence. Self-awareness is the ability to be assertive of other people's thoughts and actions. Self-regulation refers to an individual's ability to manage and alter their emotions. Social awareness refers to the ability to understand the emotional dynamics of a group or a society. Social Influence refers to the extent to which a group or a society can have effect on emotional dynamics. Self-awareness and self-regulation work in unison and social awareness work together with social influences. As entrepreneurs interact professionally emotionally intelligent people produce win-win relationships and outcomes for themselves and others. Such people develop effective professional networks and are effective at building network of social relationships and emotional support structures. Entrepreneurs with low emotional intelligence, on the other hand, enter into counterproductive professional networks. Consequentially, a field of emotional repulsion is created thus, leading to the failure to develop entrepreneurial professional networks.

\section{Research Methodology}




\section{Macrothink}

Emotional intelligence affects all people, but entrepreneurs due to their busy schedules are tantamount to lots of pressure both at work and in their personal lives. Little research has been done in Botswana on the manufacturing sector, especially emotional intelligence's effects on networking among manufacturing SMME owners. Studying emotional intelligence and professional networking of manufacturing SMMEs is critical because it helps to advise entrepreneurs on how they can become more emotionally stable, thereby improving their networking skills. By so doing the manufacturing sector can be transformed and help alleviate poverty and reduce unemployment. Due to the fact that Manufacturing SMMEs were being considered for the study, purposive sampling technique was adopted for the study. This study population is limited to the manufacturing SMME's in Gaborone, Botswana. Gaborone is the capital city of Botswana and has the largest population of businesses in the country, with over 200000 dwellers. This makes the sample chosen to be as representative as possible of the whole country. The philosophy adopted in this study is Pragmatism, which advocates that there are many different ways of interpreting the world and undertaking research, that no single point of view can ever give the entire picture and that they may be multiple realities (Lewis, Thornhill, \& Saunders, 2007). A qualitative methodology was adopted in this survey. Structured face-to-face interviews were administered to a sample of 10 manufacturing SMMEs based in Gaborone, Botswana. For the effectiveness of the interviews, the interviews took place face-to-face to observe body language and to see the work done by the interviewees. The interview started with more general introductions, some questions on personal habits, and personal level of emotional intelligence; then followed by questions on professional networking and the interviewees' strengths and weaknesses in professional networking (Collis \& Hussey, 2013; Dawson, 2009). Data collection was distributed over a period of two weeks to allow enough time to be allocated to each of the 10 interviewees. Also this was in cognisance of the fact that entrepreneurs are extremely busy people, which made it difficult to interview all of them in one or two days. Each interview ranched from 18 to 25 minutes in length.

\subsection{Empirical Results}

\subsubsection{Demographic Profiles}

Ten manufacturing SMME owners in Gaborone, Botswana, were administered with a structured interview. Table 1 below shows the demographic information of participant. 
Table 1. Nationality, marital status and ages of the respondents by gender

\begin{tabular}{|c|c|c|c|c|c|c|c|}
\hline & \multicolumn{2}{|l|}{ Male } & \multicolumn{2}{|l|}{ Female } & \multicolumn{2}{|l|}{ Total } \\
\hline & & Frequency & Percent & Frequency & Percent & Frequency & Percent \\
\hline \multirow{4}{*}{$\begin{array}{l}\text { Nationality of } \\
\text { the Respondent }\end{array}$} & Motswana & 0 & 0 & 3 & 0 & 3 & 30 \\
\hline & Zimbabwean & 5 & 71 & 0 & 0 & 5 & 50 \\
\hline & Malawi & 1 & 14.5 & 0 & 0 & 1 & 10 \\
\hline & Tanzania & 1 & 14.5 & 0 & 0 & 1 & 10 \\
\hline & Total & 7 & 100 & 3 & $\mathbf{0}$ & 10 & 100 \\
\hline \multirow{4}{*}{ Marital Status } & Single & 4 & 57 & 1 & 33.33 & 5 & 50 \\
\hline & Married & 3 & 43 & 1 & 33.33 & 4 & 40 \\
\hline & Divorced & 0 & 0 & 1 & 33.33 & 1 & 10 \\
\hline & Total & 7 & 100 & 3 & 100 & 10 & 100 \\
\hline \multirow{3}{*}{$\begin{array}{l}\text { Age } \\
\text { Categorised }\end{array}$} & $20-40$ & 5 & 71 & 3 & 100 & 8 & 80 \\
\hline & $41-79$ & 2 & 29 & 0 & 0 & 2 & 20 \\
\hline & Total & 7 & 100 & 3 & 100 & 10 & 100 \\
\hline
\end{tabular}

Source: (Data Collection, 2015).

Table 1 shows the relationship between SMMEs' gender, marital status, age and nationality. $50 \%$ of the respondents were of Zimbabwean origin and all were men. Of the 5 Zimbabwean men, $30 \%$ were single and $20 \%$ married. The ages of Zimbabwean men $-30 \%$ were aged 20-40; while 20\% were aged 41-79. 30\% were Batswana and all were female of age 20-40. Among the Batswana ladies, one female was divorced, one single and one married. The other countries represented in the sample were Malawi (10\%) and Tanzania (10\%). Fig 2 below shows distribution of respondents according to their business line. 


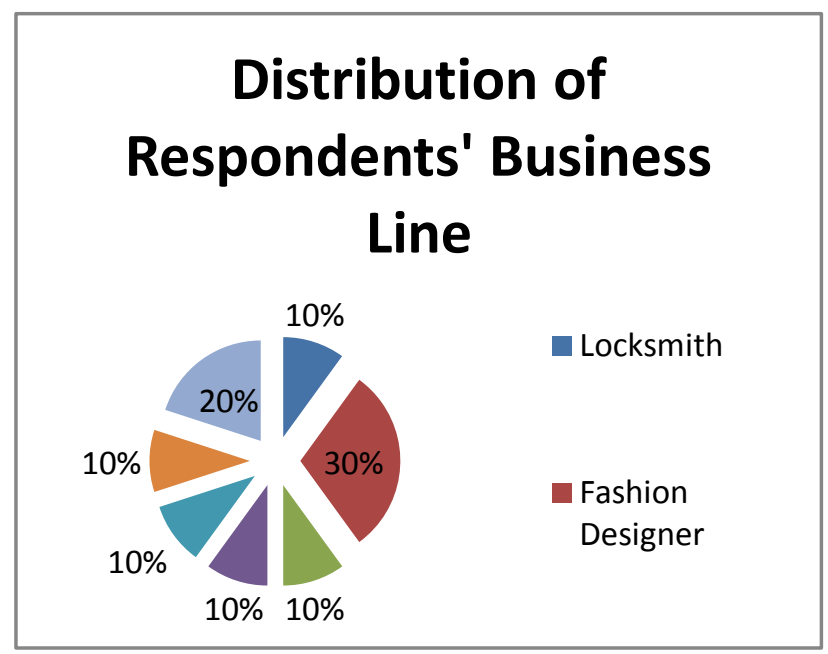

Figure 2. Distribution of respondents' business line

Source: (Data Collection, 2015).

According to Figure 2, the SMME participants comprised of 30\% involved in Fashion designing, 20\% were involved in food and beverage processing, the rest of the categories were $10 \%$ each.

\section{Major inspiration to SMME owners}

Some of the SMME owners mentioned that they were inspired by their parents who worked very hard and in some cases; the parents had been involved in the same business in the past. Some said that they were inspired different successful people such as Strive Masiyiwa and Martin Luther King. However, some SMME owners expressed appreciation for some successful firms in their line of business that have gone through thick and thin, but emerged victorious.

\section{Ways in which SMME owners have fun}

Many of the SMME owners have fun by watching television, reading books; playing either soccer, chess, draft or golf; spending time with friends; going to Church, dancing and taking family out; and socializing with family.

\section{Aspect of work that SMME owners are passionate about}

SMME owners mentioned that they are "passionate about production", others are passionate about: "administration and marketing", "cutting and designing", "production and marketing", "problem-solving" and "technical part". Majority of the SMME owners showed that they are passionate with production rather than activities to do with mingling with people out there. This might be a sign of lack or distaste for networking.

\section{Two personal habits that make SMME owners successful}

The study found out that most SMME owners have adopted habits such as reading books; 
daily physical exercise; spend much time at work, for example, one participant said: "I spend long working hours from 830am to $11 \mathrm{pm}$ "; sleep only 6 hours per day; daily research; morning meditation, prayer and praising God; asking questions; and good interaction with others - networking.

\section{Emotional challenge faced by SMME owners each day?}

SMME owners had various responses to this question. Some of the responses were as follows: "I am not comfortable with telling off others when need be", "waking up in the morning", "I set high standards and I don't like people that question me. I like space, "I find it hard to find good employees"; "I am quiet. So sometimes employees take advantage of me", "difficult customers", "financial strain", "intense feelings all at once comprising of doubt, passion, confusion and fear", "difficult customers that shout after having given us wrong instructions for their job", "workmate always drunk at work", "juggling family and business especially because I work with my spouse", "customers giving us jobs at short notice, but they expect excellent work to be done", "when juniors or colleagues don't meet targets".

\section{What makes SMME owners angry?}

The study revealed varying responses from SMME owners such as the following: one person said, "I get angry when someone disrespect me, not performing and give excuses". Another participant said, "I am annoyed by customers that don't pay." Yet another one responded: "I am irritated by laziness." One man getting emotional said, "I hate it when my workmate insults customers when he is drunk." Another mentioned, "I get angry when a customer begs us to do a job in a hurry; yet when mistakes happen in the process, the customer comes shouting at us." Another person reiterated that he gets angry due to laziness. Another one had this to say, "I get angry at people that undermine me and take advantage of me." This other lady said, "I don't like it when people don't perform." Out of the ten respondents, there is only one person who said that she doesn't get angry which means she has a very high level of emotional intelligence compared to other participants.

\section{How good are SMME owners at asking for help?}

Four out of the ten respondents admitted that they are not good at asking for help. One of these people actually said, "I don't want to share my vision with everyone, so asking for help makes it kind of difficult." The other six participants said that they were either good or very good. Here is what one of the participants said: "I am very good at asking for help. I don't hesitate to ask for assistance. If you don't ask for help, you put yourself in bigger problems." It was impressive to note that $60 \%$ of the participants were good or very good at asking for help; which is a very crucial aspect of emotional intelligence.

\section{At work, do SMME owners consider themselves a high or low energy person?}

The study revealed that most manufacturing SMMEs are high to very high energy people. This was illustrated by $80 \%$ of the respondents that said they were high or very high energy people. Some of the outstanding responses from the high energy SMMEs were as follows: "I am a high energy person. I am more than motivated to run with my vision and it gives me the 
energy." Another excitedly said, "I am a high energy person. If I can't do anything for myself, who can do it?" with exuberance, the other participant said, "I am high energy - maximum voltage." From this it can be concluded that success in business is partly due to high energy levels. However, $20 \%$ of the participants responded differently showing that some Manufacturing SMMEs lack the necessarily energy. One said, "It depends on the day and mood. I am average," and the other one said, "When I do what I love and I am working in a supportive environment; I become a high energy."

\section{At work, are SMME owners' main focus on results and tasks or people and emotions?}

According to $20 \%$ of the participants, SMME owners are to focus on results and not people factor. One of them said, "My main focus is results. This helps me to keep customers happy"; while another one said, "I focus on results and tasks. People will always be people and I can't change them. But I can influence the result or delivery of tasks." However, according to 80\% of respondents, SMME owners need to focus on both results and tasks as well as on people and emotions. Some of the proponents of both focuses mentioned this: "both results and tasks; people and emotions"; "Both morale of employees and results"; and "a bit of both is necessary. At times results are not everything. SMME owners should play hard and work hard." As $80 \%$ of participants suggested, SMME owners need a balance in the work place as one extreme can be detrimental to the establishment.

\section{How could SMME owners create more balance in your personal and business life?}

Majority of SMME owners $(60 \%)$ admit that it is difficult to strike a balance between work and personal life. This is the main challenge of SMME owners in that they concentrate on business and neglect their lives. This negatively affects their emotional intelligence and ultimately impact negatively on networking. One participant said, "I am not balancing. Personal life is strained. To solve the challenge I will hire a hands-on assistant." Another one put it this way, "I never have time for myself. I can forget a medical doctor's appointment. To solve this, I intend to introduce personal activities such as swimming and reduce disorders." According to $40 \%$ of participants, it is possible for SMME owners to balance their lives. One of the proponents of balance said, "I balance my life by going to Church. Also when I am under pressure of work I inform customers so that they don't over expect. We also sub-contract others to balance our activities." Another participant advocated planning and delegating tasks as good ways of bringing a balance in business and life.

\section{How often do SMME owners fail as entrepreneurs because of low energy levels in entrepreneurship?}

The study revealed that $30 \%$ of SMME owners don't fail due to low energy levels; while $70 \%$ sometimes face low energy levels due to challenges with customers, suppliers or employees. This signifies that although majority of the SMME owners are generally high energy people; it is not all the time that business people carry energy. There are times when they are down. During down moments SMME owners need to learn how to maintain emotional intelligence so that their networks won't suffer.

\section{Steps suggested for SMME owners' satisfaction}


Participants responded on a diverse manner to this question. Some said, "Mix work with fun. Develop patience at work and patience after work." Another participant indicated, "Create more time for personal life." After this, another respondent highlighted, "Hire highly qualified people to avoid exhaustion." Then a lady said, "Create a schedule for personal things, such as helping children with their homework. Also delegate some duties." Another participant indicated that, "Be true to self. Be diligent and carry integrity whilst pursuing your vision." Similarly, someone said, "Create personal time and also attend work-related workshops." Then another mentioned, "Hire skilled people and be willing to pay them well." The next participant said, "Get financial backing. Buy enough equipment." Of particularly interest is that almost all SMME owners supported the notion of getting satisfaction and create balance for the business and personal life which enhances emotional intelligence.

\section{Does professional networking help entrepreneurs to achieve their goals?}

According to $10 \%$ of respondents, SMME owners should not bother networking because "it is not helpful. Just please your customers and they will keep patronising you." This notion represents a minority of SMME owners that don't believe in entrepreneurial networking. On the other side, $90 \%$ of respondents believed that professional networking helps SMME owners to achieve their dreams. Someone said, "Yes. Sharing ideas can advance you." Similarly one male said, "Yes. When you team up with others, you get help from others' input and skills." At the same time, one person responded, "Yes. In our field we go to workshops in South Africa. It helps us get cheaper supplies and contacts. It also helps to be able to refer customers to other companies." The last person said, "Yes. Professional Networking has worked for me. I have contacts with other business people in South Africa." As this study demonstrates, professional networking opens new doors for profitability and growth (Kay, 2010).

\section{Strengths and Weaknesses of SMME owners when networking?}

Almost all participants mentioned that they varying strengths and weaknesses ranging from self-confidence, networking skills, passion for research, good reputation. Weaknesses included language and cultural barriers, shyness and lack of confidence, no time for networking, trusting people too much and being taken for granted, poor with computers thereby losing high-tech type of customers. Overall this question challenged participants to self-reflect on strengths and weaknesses so as to change their lives and business.

\section{Handling embarrassment in networking}

$70 \%$ of the SMME owners said that they had never been embarrassed in networking. This might be a sign of them being too careful and avoid confrontations and ridicule. $30 \%$ agreed that they had been embarrassed before. One of them said, "At a networking event, someone passed a dirty joke on my car because it was old. I didn't take it personally. We later became business partners." Another person said, "I lost a tender at one time because I was not ready and my opponent was ready." Similarly, another participant, "I lost potential customers because I didn't have email or the social platform WhatsApp."

Does the environment play an important role in providing stimulating environment for 


\section{professional networking among entrepreneurs?}

According to $50 \%$ of SMME owners, the environment in Botswana is conducive to professional networking. However, 50\% doubted that the environment is suitable for sustainable professional networking. Overall, it can be concluded that Botswana is an emerging market with lots of potential for growth. Therefore, SMME owners need to take advantage of the development rather than being negative minded and miss out (Gazette Botswana, 2012).

\section{SMME owner's advice for enhancing professional networking}

Various positive responses came forth: "Do it right the first time and don't compromise quality for value. The first 3 minutes says a lot." "Speak to newspapers. Be transparent. Avoid too many orders that you can't manage to deliver." "Use social media such as LinkedIn. Play sport such as golf." "Work normal hours and have time for networking." "Join relevant associations in your field", "Hold workshops and seminars to boost knowledge and skills." "Learn to share, listen, and give an opinion when and if it's needed. Understand the person you are dealing with." "Network more."

\section{Discussion of Findings}

The results of the research shows a link with studies by (Hafer \& Jones, 2014) and (Suleiman Awwad \& Kada Ali, 2012) who found out that higher the entrepreneurs' EI, the more they are able to produce creative and useful ideas and network effectively. Entrepreneurs have the abilities to understand and regulate the emotions of themselves and others and use the emotions to facilitate performance. Furthermore, according to our findings, workshops and seminars can enhance emotional intelligence.

The research has also shown that entrepreneurs have an understanding of EI aspects relating to self-awareness, social awareness and social influence. This therefore validates the practical application of the model on EI by (Kunnanatt, 2004). Pursuing this line of argument further, some of the entrepreneurs have adopted such habits such as mediation and interaction with others. Furthermore, the research also highlighted that entrepreneurs also face emotional challenges on a daily basis these include, setting goals, handling difficult customers, work life balance issues and managing employees. The respondents also identified that this concept was deeply intertwined in the notion of energy levels; high energy levels were considered to be essential for emotional intelligence to thrive. The findings also correlate with findings by (Chipfuva et al., 2012; Hafer \& Jones, 2014; Suleiman Awwad \& Kada Ali, 2012; Thi Thanh Thai et al., 2013)

One interesting aspect emanating from the research was that $60 \%$ of the respondents alluded to the fact that obtaining help was essential part of emotional intelligence. Furthermore, $90 \%$ of the respondents highlighted that obtaining help enabled them to develop professional networking skills; only $10 \%$ did not see the value of developing professional networks. This therefore validates the findings made by (Hafer \& Jones, 2014; Thi Thanh Thai et al., 2013). The entrepreneurs who accessed a formal business network asserted that opportunities were afforded through the network events. Secondly, the entrepreneurs indicated that the main 


\section{Macrothink}

benefits of networking were advice; friendship; information sharing and training opportunities. Thirdly, entrepreneurs develop entrepreneurial professional networks using a variety of methods. These methods include networking with community of their own nationality; engaging with other members of the local business community and international networks.

Taking into cognisance the results presented and the discussion of findings Fig 3 illustrates how EI can be used to as tool for effectively developing entrepreneurial networks. Entrepreneurs value social relations as essential part in emotional intelligence, for instance in the research most entrepreneurs value spending time with family, socialising and interacting with others, this in essence is important in EI.

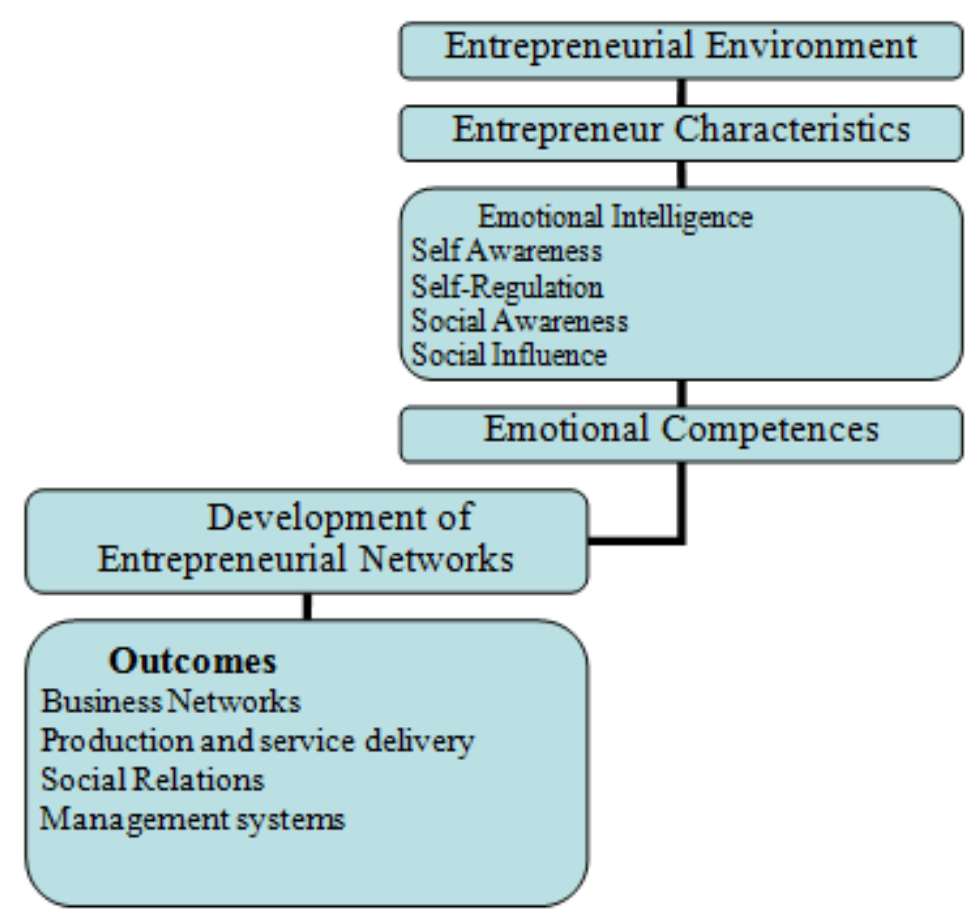

Figure 3. A framework depicting Emotional Intelligence as a tool for effectively developing networks

Source: (Research Findings, 2015).

Figure 3 above represents the interface and the interrelations that exist which enables EI to be effectively used as a tool for developing professional networks. The entrepreneurial environment which is context specific provides a platform for EI to thrive. This environment includes aspects relating to the business environment and challenges the entrepreneur face in terms of executing their day to day entrepreneurial activities such as handling customer demands. Entrepreneur characteristics focus on the attributes of a specific entrepreneur such 
as personality, goal orientation and so forth. Entrepreneurial characteristics influence the level of EI in the form of self-awareness, self-regulation, social awareness and social influence. Emotional competence would then be the ultimate outcome of effectively applying the concept of EI. Effective emotional competence will enable an entrepreneur to effectively manage their own emotions and also the emotions of others, leading to the development of entrepreneurial professional networks. Thus, the impact of developing networks will be on business networks, production and service delivery, social relations and management systems.

\section{Conclusion}

The study revealed that most entrepreneurs' value time spent at work, managing their emotions, social relations and personal lives. Most of the entrepreneurs interviewed in this study demonstrated a high level of understanding the essence of developing entrepreneurial networks. Nevertheless, the entrepreneur's low levels of EI can negatively affect their level of networking. This paper motivated a debate on the link between EI and the development of professional networks and how these variables determine Entrepreneurial success. While there appears to be a clear relationship between EI and the development of entrepreneurial networks measurement instruments that can show the contributions of each variable to entrepreneurial success need to be contextualised. Thus, entrepreneurs should focus on understanding their specific entrepreneurial environment; develop EI techniques and business acumen skills. Ultimately, effectively applying the techniques of EI impacts on the macro and micro relationships of business and cultivates a host of virtues and attributes which contributes to entrepreneurial success.

\subsection{Limitations and Further Studies Suggested}

This study has provided important insights of interest, to entrepreneurs, scholars and policy makers. However the research was based on a qualitative methodology, future research can be undertaken using a mixed methodology. Furthermore additional research can be undertaken using a comparative analysis of different African countries in order to come up with a multifaceted approach to the role of EI in the development of entrepreneurial professional networks.

\section{References}

Briere, S., Tremblay, M., \& Daou, A. (2014). Entrepreneurship in South Africa: looking beyond funding. Development and Learning in Organizations, 28(2), 17-19.

Brooks, K., \& Muyia Nafukho, F. (2006). Human resource development, social capital, emotional intelligence: any link to productivity? Journal of European Industrial Training, $30(2), 117-128$.

Chinyoka, S., \& Muranda, Z. (2013). Franchisees' and Independent Entrepreneurs' Skills: Policy and Strategy Implications. Botswana Journal of Business, 6(1), 44-59.

Chipfuva, T., Nzonzo, J. C., \& Muchenje, B. (2012). Challenges faced by women entrepreneurs in the tourism sector in zimbabwe. International Journal of Social and Allied 
Research (IJSAR), 1(1), 25-33.

Collis, J., \& Hussey, R. (2013). Business research: A practical guide for undergraduate and postgraduate students. Palgrave macmillan.

Dawson, C. (2009). Introduction to research methods: A practical guide for anyone undertaking a research project. Hachette UK.

Galkina, T. (2013). Entrepreneurial networking: Intended and unintended processes.

Gazette Botswana, B. (2012). National Development Plan 11. Gaborone: Botswana Government Printers.

Hafer, R., \& Jones, G. (2014). Are entrepreneurship and cognitive skills related? Some international evidence. Small Business Economics, 1-16.

Hallen, B. L., \& Eisenhardt, K. M. (2012). Catalyzing strategies and efficient tie formation: how entrepreneurial firms obtain investment ties. Academy of Management Journal, 55(1), $35-70$.

Jefferis, K. (2014). The New Policy on Small, Medium \& Micro Enterprises. Retrieved February 11, 2015, from http://www.bidpa.bw

Kaplan, J. M., \& Warren, A. C. (2009). Patterns of entrepreneurship management. John Wiley \& Sons.

Kay, F. (2010). Successful Networking: How to Build New Networks for Career and Company Progression. Kogan Page Publishers.

Kunnanatt, J. T. (2004). Emotional Intelligence: The New Science of Interpersonal Effectiveness. Human Resource Development Quarterly, 15(4), 489-495.

Lewis, P., Thornhill, A., \& Saunders, M. (2007). Research methods for business students. Pearson Education UK.

Makgosa, R., \& Ongori, H. (2012). Perceptions of entrepreneurial behaviour in Botswana. International Journal of Learning and Development, 2(3), Pages 247-259.

Money, C. (2012). Face Book reaches 1 Billion Users. Available online. Retrieved May 29, 2015, from http://money.cnn.com/2012/10/04/technology/facebook-billion-users/i ndex.htm

Neneh, N., \& Van Zyl, J. (2013). Achieving optimal business performance through business practices: evidence from SMEs in selected areas in South Africa. Southern African Business Review, 16(3), 118-144.

Oriarewo, G. O., Agbim, K. C., \& Zever, T. A. (2014). Relationship Between Emotional Intelligence And Entrepreneurial Performance: The Mediating Effect Of Entrepreneurial Competence. Australian Journal of Business and Management Research, 4(8), 1.

Pansiri, J., \& Temtime, Z. T. (2008). Assessing managerial skills in SMEs for capacity building. Journal of management development, 27(2), 251-260. 


\section{Macrothink}

Journal of Entrepreneurship and Business Innovation ISSN 2332-8851

Prakash, D., Jain, S., \& Chauhan, K. (2015). Entrepreneurial intensity in relation to presence of entrepreneurship development cell: A study of institutes offering professional courses in national capital region Delhi, India. The International Journal of Management Education, 13(1), 95-105.

Suleiman Awwad, M., \& Kada Ali, H. (2012). Emotional intelligence and entrepreneurial orientation: The moderating role of organizational climate and employees' creativity. Journal of Research in Marketing and Entrepreneurship, 14(1), 115-136.

Sullivan, D. M. (2006). Dynamic Entrepreneurial Networks: An Investigation of Entrepreneurs, New Ventures and Their Networks. University of Central Florida Orlando, Florida.

Thi Thanh Thai, M., Turkina, E., \& Stephens, S. (2013). Building an entrepreneurial network: the experiences of immigrant entrepreneurs. Journal of Enterprising Communities: People and Places in the Global Economy, 7(3), 233-244.

Thoma, A., Nguyen, L., \& Kupsyte, V. (2014a). Enterpreneurial network. Unpublished Masters Thesis, Roskilde.

Thoma, A., Nguyen, L., \& Kupsyte, V. (2014b). Enterpreneurial network.

\section{Copyright Disclaimer}

Copyright for this article is retained by the author(s), with first publication rights granted to the journal.

This is an open-access article distributed under the terms and conditions of the Creative Commons Attribution license (http://creativecommons.org/licenses/by/3.0/). 